\title{
肝臓での代謝および輸送における薬物間相互作用の定量的予測 Quantitative Prediction of Drug Interation Involving Metabolism
and Transport in the Liver
}

\author{
杉山 雄一, 加藤 将夫, 金光 真一, 伊藤 清美* \\ (東京大学大学院薬学系研究科 製剂設計教室)
}

\author{
Yuichi SugiYama, Yukio Kato, Shin-ichi Kanamitsu and Kiyomi Ito* \\ Graduate School of Pharmaceutical Sciences, University of Tokyo, Tokyo; \\ *School of Pharmaceutical Sciences, Kitasato University, Tokyo
}

\begin{abstract}
Summary: When the metabolism of a drug is competitively or noncompetitively inhibited by another drug, the degree of in vivo interaction can be evaluated from the Iu/Ki ratio, where Iu is the unbound concentration around the enzyme and $\mathrm{Ki}$ is the in vitro inhibition constant of the inhibitor. In the case of tolbutamide/sulfaphenazole interaction, the increase in tolbutamide AUC predicted using an estimated maximum value of Iu was comparable with the predictions taking the concentration profile of the inhibitor into consideration and also with the in vivo observation.

We have also evaluated the metabolic inhibition potential of a number of drugs known to be inhibitors or substrates of cytochrome P450 (CYP) by estimating their Iu/Ki ratio using literature data. Using the maximum unbound concentration of the inhibitor at the inlet to the liver as Iu, the possibility of drugs causing in vivo drug-drug interactions could be predicted based on their $\mathrm{Iu} / \mathrm{Ki}$ ratios.

On the other hand, in the case of interactions involving a mechanism-based inhibition, it is necessary to consider the exposure time of the enzyme to the inhibitor and enzyme turnover in predicting from in vitro data. A case of 5 -fluorouracil/sorivudine interaction has been predicted based on a physiologically-based pharmacokinetic model.

Although it can be assumed for most inhibitors that the value of $I u$ is equal to the unbound concentration in the liver capillary, this assumption is not valid if the inhibitor is actively taken up by the liver. In the in vitro uptake studies using isolated rat hepatocytes and ATP depletors, none of the investigated inhibitors was found to be highly concentrated in the liver, and the predicted in vivo interaction was not greatly affected by taking account of active transport of the inhibitor.

We have also attempted to establish a rational methodology for predicting the drug interactions via hepatic transporters responsible for drug uptake and subsequent excretion. Both isolated hepatocytes and canalicular membrane vesicles were used to determine the intrinsic potential for the interaction via hepatic uptake and biliary excretion at the sinusoidal and canalicular membranes, respectively. We have demonstrated that the degree of inhibition of each membrane transport process can be accurately estimated also by considering the $\mathrm{Iu} / \mathrm{Ki}$ ratios. We have also established a rational methodology to predict the degree of inhibition of net biliary excretion (from blood to bile) which can also be applied to clinical situations and prevent researchers from making false negative predictions.
\end{abstract}

Key words: Quantitative prediction, Metabolism, Active transport, Biliary excretion, Physiologicallybased pharmacokinetics

\section{1. はじめに}

薬物間相互作用により体内動態が変動する主な原因と して，以下のことをあげることができる.(1) 薬物吸収 に関する相互作用，(2) 血漿蛋白結合に関する相互作
用，(3) 輸送担体による生体膜透過過程に抢ける相互作 用(肝, 腎への取り込み, 胆汁, 尿中排泄過程を含む), (4) 代謝過程に打ける相互作用. さらに, 薬物受容体に おける捛抗作用などのようなファーマコダイナミクスに 関する相互作用によっても, 薬物の作用が増強あるいは 
減弱される可能性がある.

本稿においては，臨床上特に問題となりうる(3)抢よび (4)を中心に，ヒ卜組織を用いたin vitro 試験から in vivo での薬物間相互作用の定量的予測の可能性について 議論したい，薬物代謝の阻害に起因する体内動態変化を in vitro 試験から予測する手法として，一般的な競合阻 害のケースのみでなく, より重篤な副作用につながる危 険性のある mechanism-based inhibitionのケースについ ても定量的な予測を試みた例を紹介する.

\section{2. 薬物代謝の競合あるいは非競合阻害に 基づく In vivo 薬物間相互作用の 定量的予測}

臨床における基質濃度は多くの場合，Km と比較して 十分低く，代謝阻害の程度 $(\mathrm{R}=\mathrm{AUC}$ (+inhibitor)/ AUC (control)) は競合阻害と非競合阻害の場合, $\mathrm{R}=1+\mathrm{Iu} / \mathrm{Ki}$ とあらわされる.ここで, Iu は酵素近傍

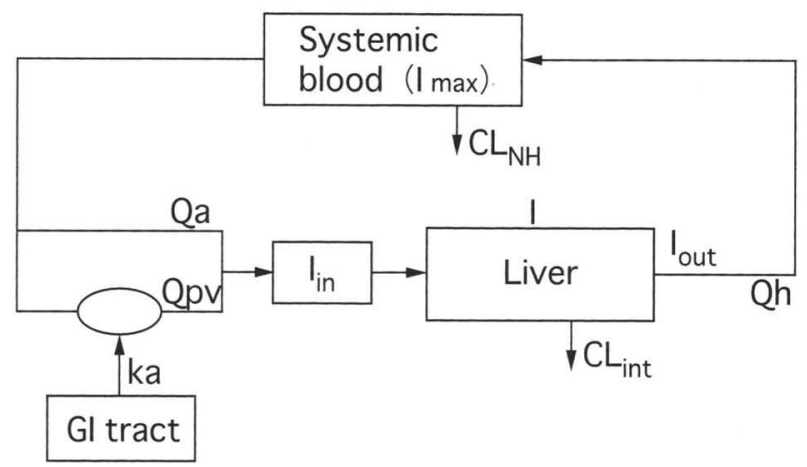

Fig. 1 Model for estimating the concentration of the inhibitor at the inlet to the liver after oral administration $\left(\mathrm{I}_{\text {in }}\right)$. $\mathrm{I}_{\text {out }}, \mathrm{I}$, and $\mathrm{I}_{\max }$ represent the inhibitor concentration at the exit of the liver (hepatic vein side), the inhibitor concentration at the liver capillary, and maximum inhibitor concentration in the systemic circulation, respectively. Qa, Qpv and $\mathrm{Qh}(=\mathrm{Qa}+\mathrm{Qpv})$ represent the blood flow at the hepatic artery, portal vein, and hepatic vein, respectively.
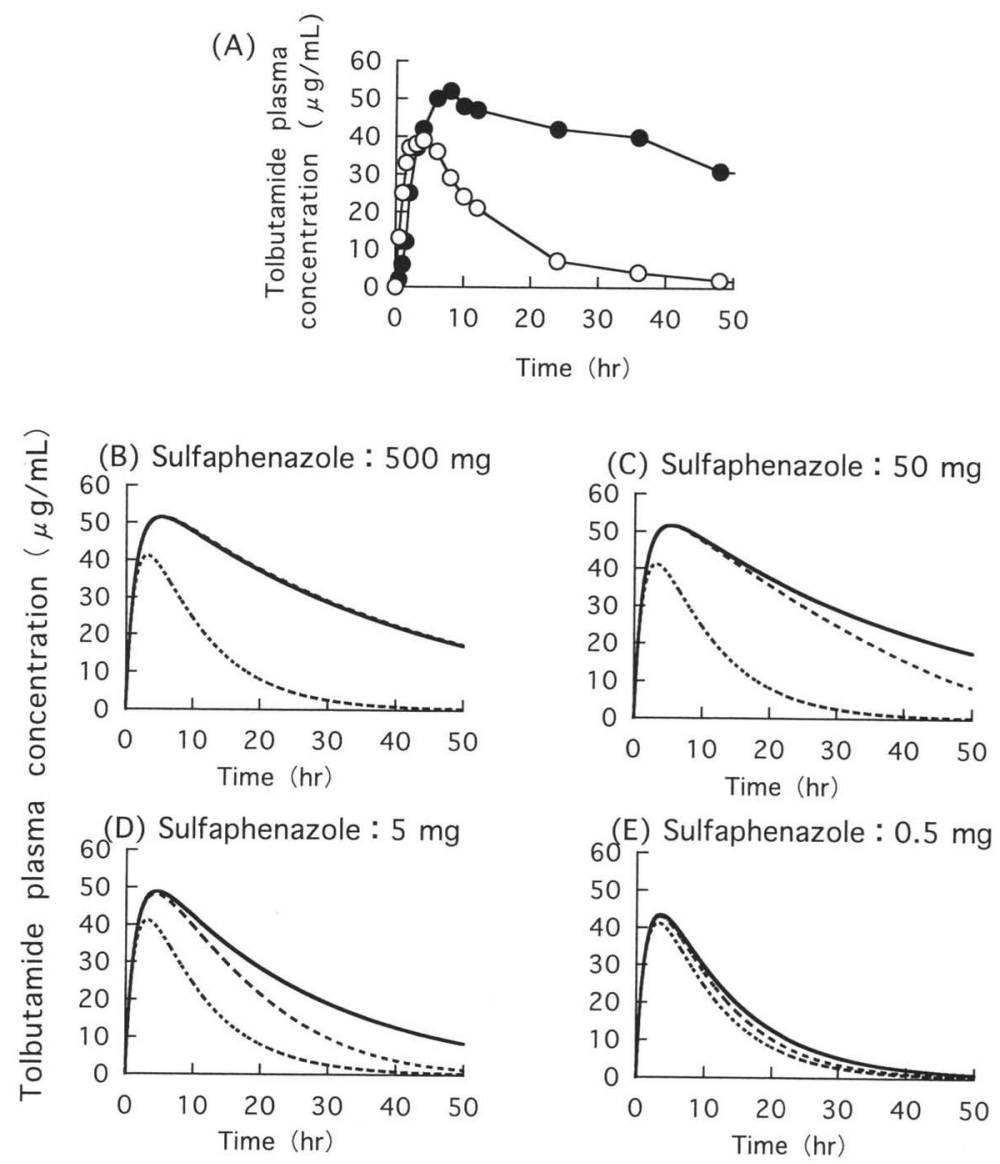

Fig. 2 Prediction of the interaction between tolbutamide and sulfaphenazole.

Panel (A) represents the plasma concentration profiles of tolbutamide in humans reported by Veronese et al. (1990). Open circles: control, closed circles: co-administration of sulfaphenazole (500 mg, b.i.d.).

Panels $(\mathbf{B}),(\mathbf{C}),(\mathbf{D})$, and $(\mathbf{E})$ represent the simulated effect of co-administration of sulfaphenazole at a dose of $500,50,5$, and $0.5 \mathrm{mg}$, respectively, on the plasma concentration profile of tolbutamide.

-.... control, ---: co-administration of sulfaphenazole, _- simulation using a fixed concentration of sulfaphenazole $\left(\mathrm{I}_{\mathrm{in}, \mathrm{u}}\right)$. 
における阻害剤の非結合型濃度, Ki は肝ミクロソーム 等を用いたin vitro 代謝試験で得られる阻害定数を示 す.ヒトに掞いて Iuの正確な值を見積もることは困難 であるので, 我々は false negative な予測を避けるた め, 肝動脈血と門脈血が合流して肝臓へ流入する部分の 血中最大非結合型濃度 $\left(\mathrm{I}_{\mathrm{in}, \mathrm{u}}\right)$ を $\mathrm{Iu}$ の最大值と考え,

Fig. 1 の生理学的モデルにしたがって以下の式により 阻害剂経口投与時の $I_{\text {in, u }}$ を推定した.

$$
\mathrm{I}_{\text {in, } \mathrm{u}}=\left(\mathrm{I}_{\max }+\frac{\mathrm{ka} \cdot \mathrm{D} \cdot \mathrm{Fa}}{\mathrm{Qh}}\right) \times \mathrm{fu}
$$

ここで, $\mathrm{I}_{\max }$ は阻害剤の循環血中最大濃度, $\mathrm{ka}$ は消化 管からの吸収速度定数, D は投与量, $\mathrm{Fa}$ は吸収率, Qh は肝血流量, fu は血中非結合型分率をあらわす。 た, 文献情報より得た $\mathrm{Ki}$ 值との比較から, in vivoでの 薬物間相互作用の程度を見積もった結果, tolbutamide/ sulfaphenazole (CYP2C9 における相互作用), triazolam/ketoconazole (CYP3A4 における相互作用) 等の組 み合わせについて, ヒト in vivoでの相互作用の定量的 予測が可能であったことを報告した ${ }^{1,2)}$.

一方, 実際には阻害剤濃度は時々刻々と変化するもの であることから, tolbutamide/sulfaphenazole の相互作 用を例にあげて, 阻害剤濃度推移を考量した予測を試み た. Fig. 1 のモデルに基づいて物質収支式を立て, 文 献情報より得られた両薬物の体内動態パラメータを代入 して数值的に解くことにより, tolbutamide の血中濃度 推移をシミュレーションした. その結果, Fig. 2 に示 すように, Iu を上記の $\mathrm{I}_{\mathrm{in}, \mathrm{u}}$ に固定して予測した場合と comparable な結果が得られ, sulfaphenazole 非投与群 と比較して sulfaphenazole (500 mg)の併用により tolbutamide の AUC が 4 倍に増加することが予測され, in vivoの実測値3)とよく一致した ${ }^{4)}$. 実際の肝葴中非結 合型濃度を過大評価している $\mathrm{I}_{\mathrm{in}, \mathrm{u}}$ を用いても良い予測 が得られた理由として, sulfaphenazole の臨床投与量に 掞いては CYP2C9 関与の代謝は完全に阻害されている ものと考えられた. シミュレーションの結果, 投与量を 100 分の 1 (5 mg) に下げても tolbutamide の血中濃度 上昇が予測され, 注意が必要であることが示唆された.

\section{3. 各種阻害剤の $I u / K i$ 值に基づく In vivo 薬物代謝阻害能の評価}

薬物代謝の競合あるいは非競合阻害に基づくin vivo 薬物間相互作用を, 阻害剂の $\mathrm{Iu} / \mathrm{Ki}$ 值に基ついて予測 する方法論の妥当性を検討する目的で, 各種 CYP isozyme の阻害剂あるいは基質となることが知られている 多くの薬物 (以下, 阻害剤と略す)について, 文献情報を 用いて $\mathrm{Iu} / \mathrm{Ki}$ 値を算出し, in vivoの相互作用の報告值 と比較した. $\mathrm{Ki}$ 值はヒト肝ミクロソームあるいはヒト CYP 発現系を用いたin vitro 試験により算出されてい
るものを文献検索により調査し, Ki 值の報告がない薬 物については代わりに $\mathrm{Km}$ 值を用いた. 式(1)の $\mathrm{I}_{\max }$ と しては, 各阻害剂の血中濃度推移の報告值から線形体内 動態を仮定して, 常用量投与時の循環血中最大濃度を推 定した. ka, Fa, Qh はそれぞれ $0.1 \mathrm{~min}^{-1}, 1,1610 \mathrm{~mL} /$ min と仮定し, D には各阻害剂の常用量, fu には文献 情報より得た值を代入することにより，式(1)を用いて 各阻害剤の $\mathrm{I}_{\mathrm{in}, \mathrm{u}}$ を算出した。一方, 各阻害剤が関与す るヒト in vivoでの相互作用について, 該当する CYP isozyme の基質となる薬物の AUC 上昇率(単独投与時 のAUC に対する割合)を文献調査により得た.

Table I に示すように, 調査した阻害剤の約半数にお いて，算出された $\mathrm{I}_{\mathrm{in}, \mathrm{u}} / \mathrm{Ki}$ 值は 0.2 より小さく，そのう

Table I Relationship between $\mathrm{I}_{\mathrm{in}, \mathrm{u}} / \mathrm{Ki}$ ratio and the degree of in vivo interaction

\begin{tabular}{|c|c|c|c|c|c|c|c|c|}
\hline \multirow{2}{*}{$\begin{array}{l}\mathrm{I}_{\text {in,u }} \\
/ \mathrm{Ki}\end{array}$} & \multicolumn{7}{|c|}{ in vivo AUC \% } & \multirow{2}{*}{ Total } \\
\hline & 100 & $<120$ & $<150$ & $<200$ & $<500$ & $\geqq 500$ & $\begin{array}{l}\text { No } \\
\text { data }\end{array}$ & \\
\hline$<0.1$ & 5 & & 3 & 2 & 2 & & 30 & 42 \\
\hline$<0.2$ & 1 & & 1 & 2 & 1 & & 11 & 16 \\
\hline$<0.5$ & 2 & & & 1 & 3 & & 2 & 8 \\
\hline$<1.0$ & 1 & & 2 & 4 & 2 & & 6 & 15 \\
\hline$<2.0$ & & 1 & & & 3 & & 7 & 11 \\
\hline$<3.0$ & & & & & 1 & 1 & & 2 \\
\hline$<5.0$ & & & 1 & & 2 & 2 & 1 & 6 \\
\hline$<10.0$ & & & & & & & & 0 \\
\hline$\geqq 10.0$ & & & & & 4 & 3 & 2 & 9 \\
\hline Total & 9 & 1 & 7 & 9 & 18 & 6 & 59 & 109 \\
\hline
\end{tabular}

Table II Relationship between $\mathrm{I}_{\max , \mathrm{u}} / \mathrm{Ki}$ ratio and the degree of in vivo interaction $\sim$ Using systemic concentration

\begin{tabular}{rrrrrrrrrr}
\hline \multirow{7}{*}{$\begin{array}{c}\text { In vivo AUC } \% \\
\text { I Ki }\end{array}$} & 100 & $<120$ & $<150$ & $<200$ & $<500$ & $\geqq 500$ & $\begin{array}{c}\text { No } \\
\text { data }\end{array}$ \\
\hline$<0.1$ & 8 & 1 & 6 & 8 & 10 & 2 & 52 & 87 \\
\hline$<0.2$ & 1 & & & 1 & 1 & 1 & 4 & 8 \\
\hline$<0.5$ & & & 1 & & & 1 \\
\hline$<1.0$ & & & 2 & & 2 & 5 \\
\hline$<2.0$ & & & & 1 & & & 1 \\
\hline$<3.0$ & & & & & & & 0 \\
\hline$<5.0$ & & & & 1 & & & 1 \\
\hline$<10.0$ & & & & & 1 & 1 & 2 \\
\hline$\geqq 10.0$ & & & & 2 & 2 & & 4 \\
\hline Total & 9 & 1 & 7 & 9 & 18 & 6 & 59 & 109 \\
\hline
\end{tabular}


ち約 8 割の阻害剤についてin vivo での相互作用は報告 されていないか，あるいは「相互作用なし」と報告され ていた. 一方, 算出された $\mathrm{I}_{\mathrm{in}, \mathrm{u}} / \mathrm{Ki}$ 值が 2 より大きい阻 害剂は全体の $16 \%$ であり，そのうち約 8 割の阻害剤に ついて，2 倍以上の AUC 上昇を伴う in vivo 相互作用 が報告されていた。 また，5倍以上の AUC 上昇を伴う in vivo 相互作用が報告されている阻害剂について算出 された $\mathrm{I}_{\mathrm{in,}} / \mathrm{Ki}$ 值は，すべて 2 より大きかった。

一方, Iu として $\mathrm{I}_{\mathrm{in,} \mathrm{u}}$ ではなく, 循環血中最大非結合 型濃度 $\left(\mathrm{I}_{\max , \mathrm{u}}=\mathrm{I}_{\max } \times \mathrm{fu}\right)$ を用いた場合について，同様の 解析をした結果を Table II に示す. $I_{\max , \mathrm{u}} / \mathrm{Ki}$ 値は約 9 割の阻害剂で 0.2 より小さく，そのうち約 3 割では 1.2 倍以上の AUC 上昇を伴う in vivo 相互作用が報告され ていた。また， 5 倍以上の AUC 上昇を伴う in vivo 相 互作用が報告されている阻害剤のうち，算出された $\mathrm{I}_{\max , \mathrm{u}} / \mathrm{Ki}$ 值が 0.2 より小さいものが半数を占めた.

以上の結果より, 薬物代謝阻害に起因するin vivo 薬 物間相互作用は, 阻害剤の $\mathrm{I}_{\mathrm{in}, \mathrm{u}} / \mathrm{Ki}$ 值に基づいてある程 度定量的に予測することが可能であり，循環血中濃度の みを用いた場合には大きく過小評価される可能性がある ことが示唆された。

\section{4. 薬物代謝の Mechanism-based Inhibi- tionに基づく In vivo 薬物間相互作用の 定量的予測}

抗ウイルス薬 sorivudine とフルオロウラシル系抗癌 剤の併用による致死的相互作用の発現機構には，5fluorouracil(5-FU)の代謝律速酵素である dihydropyrimidine dehydrogenase (DPD) と sorivudine から腸内 細菌によって生成された(E)-5-(2-bromovinyl) uracil （BVU)の活性代謝物が共有結合体を形成し，DPD を不 可逆的に阻害する，いわゆる mechanism-based inhibition が関与することが明らかにされている5)。このよう な場合には, in vitro 試験により in vivoの相互作用を予 測する際, 酵素との接触時間や酵素の turnover を考慮 した解析を行うことが必要である. 我々は mechanismbased inhibition が関与する例として，ヒトに拈ける 5$\mathrm{FU} /$ sorivudine $の$ in vivo 相互作用をin vitro 試験デー タから定量的に予測することを試みた6).

ヒト肝サイトゾルおよびヒト recombinant DPD (rhDPD)を用いて，5-FU 代謝に対する BVU の阻害試 験を行った結果，いずれの酵素を用いても，NADPH 存在下でBVUと酵素を preincubationした時間と BVU 濃度に依存した阻害の増強が認められた。残存酵 素活性と preincubation 時間を片対数プロットし(Fig. 3）, 阻害の初速度がみられている領域の傾きからみか けの酵素不活化速度定数(kobs) を求めた. kobs と BVU 濃度 $(\mathrm{I}$ o) との関係を以下の式に当てはめ, 非線形
(A) rhDPD

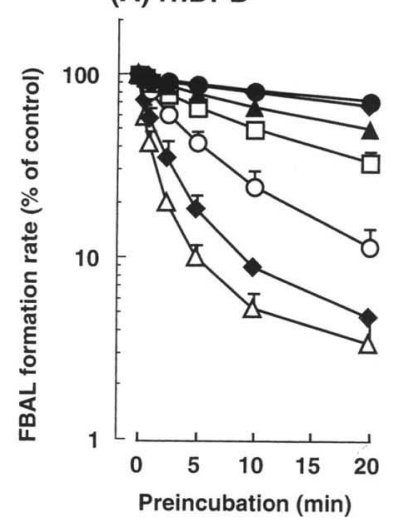

(B) Human hepatic cytosol

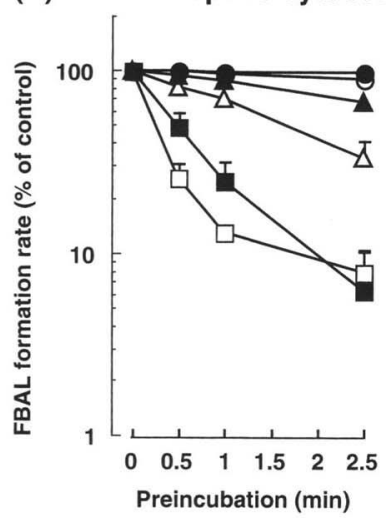

Fig. 3 Inhibitory effects of BVU on 5-FU metabolism in (A) rhDPD or (B) human hepatic cytosol.

The 5-FU metabolising activity was measured using $\left[{ }^{14} \mathrm{C}\right] 5-\mathrm{FU}$ as a substrate after preincubation of the rhDPD or cytosol with varying concentrations of BVU. BVU concentrations were $0, \diamond 0.03, \boldsymbol{\Delta} 0.1$, $\square 0.3, \bigcirc 1, \bullet 5$, and $\triangle 20 \mu \mathrm{M}$ for panel (A); 0 , $\bigcirc 1, \Delta 3, \triangle 10$, $\square 5$, and $\square 200 \mu \mathrm{M}$ for panel (B).

最小二乗法により阻害に関するパラメータ $\left(\mathrm{k}_{\text {inact }}\right.$ と K’app)を求めた。

kobs $=\mathrm{k}_{\text {inact }} \cdot \mathrm{Io} /\left(\mathrm{K}^{\prime} \mathrm{app}+\mathrm{Io}\right)$

ここで, $\mathrm{k}_{\text {inact }}$ は不活化最大速度定数, K’app は酵素と BVUのみかけの解離定数である. $\mathrm{k}_{\text {inact }}$ 打よび $\mathrm{K}$ 'app はヒト肝サイトゾルを用いた場合, $2.39 \pm 0.13 \mathrm{~min}^{-1}$ および $48.6 \pm 11.8 \mu \mathrm{M}, \operatorname{rhDPD}$ を用いた場合, $0.574 \pm 0.121 \mathrm{~min}^{-1}$ および $2.20 \pm 0.57 \mu \mathrm{M}$ と算出され た.

一方, 肝臓内の活性型 DPD (Eact) 扔よび不活型 DPD (Einact)については, 次のような微分方程式を書 くことができる.

$\mathrm{dEact} / \mathrm{dt}=-\left(\mathrm{k}_{\text {inact }} \cdot\right.$ Eact $\cdot \mathrm{fb} \cdot$ Iliver $\left./ \mathrm{Kp}\right) /$

$$
\begin{aligned}
& (\mathrm{K} \text { 'app }+\mathrm{fb} \cdot \text { Iliver } / \mathrm{Kp}) \\
& +\mathrm{k}_{\operatorname{deg}}\left(\mathrm{E}_{0}-\text { Eact }\right)
\end{aligned}
$$

$\mathrm{dEinact} / \mathrm{dt}=\left(\mathrm{k}_{\text {inact }} \cdot\right.$ Eact $\cdot \mathrm{fb} \cdot$ Iliver $\left./ \mathrm{Kp}\right) /$

$$
\begin{aligned}
& (\mathrm{K} \text { 'app }+\mathrm{fb} \cdot \text { Iliver } / \mathrm{Kp}) \\
& -\mathrm{k}_{\mathrm{deg}} \cdot \text { Einact }
\end{aligned}
$$

ここで， $k_{\operatorname{deg}}$ は DPD の分解速度定数，Kp は BVU の 肝臓中/血中濃度比, fb は BVU の血中非結合型分率, Iliver は肝蔵中 BVU 濃度, $\mathrm{E}_{0}$ は DPD の総濃度をあら わす。

5-FU のプロドラッグである tegafur, 5-FU 抢よび BVU について, Fig. 4 の生理学的モデルに基づいて以 下の微分方程式を立てた。

Tegafurについて

Vliver $\cdot(\mathrm{dPliver} / \mathrm{dt})=\mathrm{Qh} \cdot \mathrm{Ppv}-\mathrm{Qh} \cdot \mathrm{Pliver} / \mathrm{Kp}$ $-\mathrm{fb} \cdot($ CLint, $1+\mathrm{CLint}, 2)$ -Pliver/Kp 


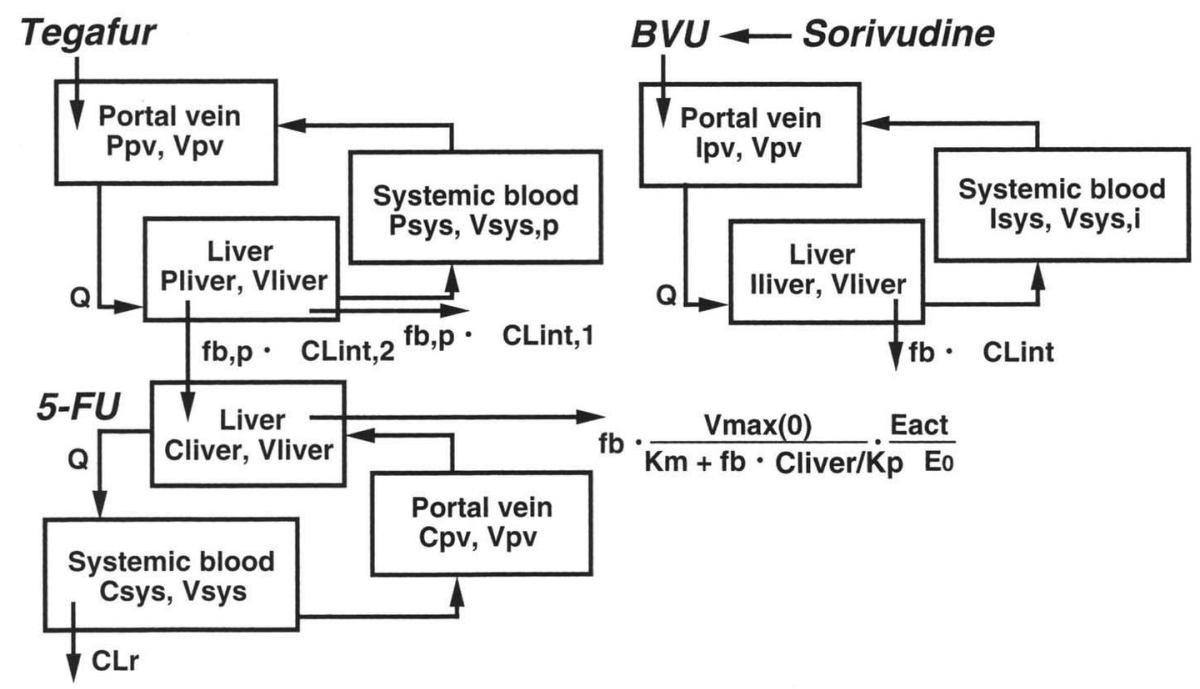

Fig. 4 Physiological model for the description of the time-profiles of tegafur, 5-FU and BVU concentrations in humans. Oral administration of tegafur (a prodrug of 5-FU) was assumed.

(A) Tegafur blood concentration

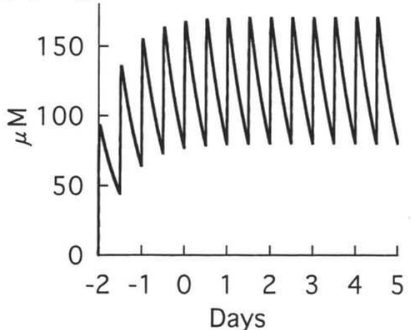

(B) BVU blood concentration

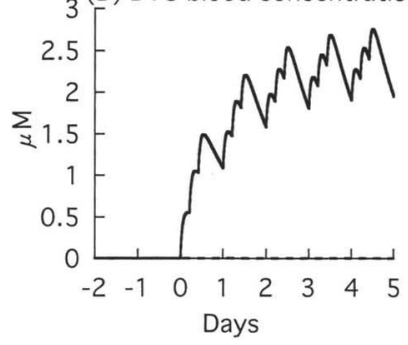

(C) Active DPD content

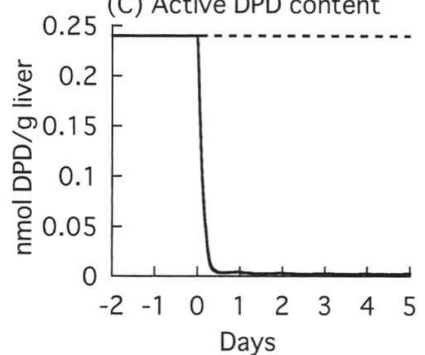

(D) 5-FU blood concentration

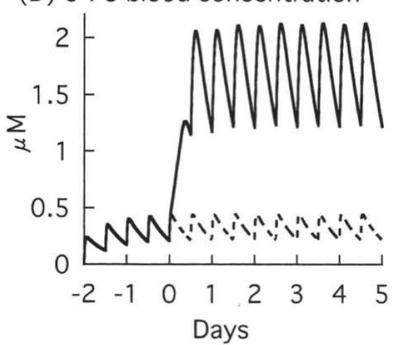

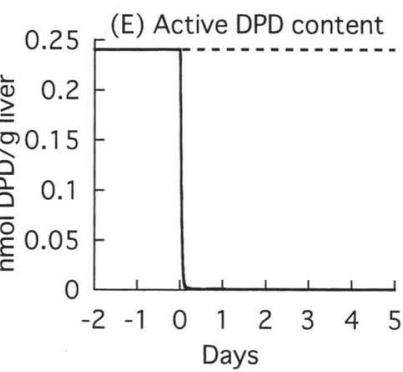

(F) 5-FU blood concentration

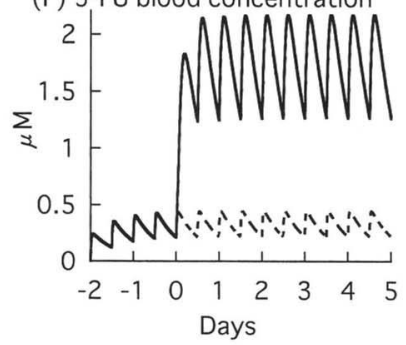

Fig. 5 Simulation of sorivudine effects on the hepatic DPD content and blood concentration of 5-FU in humans.

Time-courses of tegafur blood concentration (A), BVU blood concentration (B), active DPD content in the liver (C and $\mathbf{E}$ ), and 5-FU blood concentration ( $\mathbf{D}$ and $\mathbf{F}$ ) were simulated according to eq. (3)-(17). (C) and (D) represent simulations based on parameters obtained using human hepatic cytosol. $(\mathbf{E})$ and $(\mathbf{F})$ represent simulations based on parameters obtained using rhDPD. Broken lines; control; solid lines; co-administration of sorivudine.

$\mathrm{Vpv} \cdot(\mathrm{dPpv} / \mathrm{dt})=\mathrm{Qh} \cdot \mathrm{Psys}+\mathrm{Vabs}-\mathrm{Qh} \cdot \mathrm{Ppv}$

$\mathrm{Vabs}=\mathrm{ka} \cdot \mathrm{D} \cdot \mathrm{Fa} \cdot \mathrm{e}^{-\mathrm{ka} \cdot \mathrm{t}}$

Vsys $\cdot(\mathrm{dPsys} / \mathrm{dt})=\mathrm{Qh} \cdot$ Pliver $/ \mathrm{Kp}-\mathrm{Qh} \cdot$ Psys (8) 5-FUについて

Vliver $\cdot(\mathrm{dCliver} / \mathrm{dt})=\mathrm{Qh} \cdot \mathrm{Cpv}-\mathrm{Qh} \cdot \mathrm{Cliver} / \mathrm{Kp}-$ $\mathrm{fb} \cdot \mathrm{CLint} \cdot$ Cliver $/ \mathrm{Kp}$ $+\mathrm{fb}, \mathrm{p} \cdot \mathrm{CLint}, 2$

- Pliver/Kp, tegafur

$$
\text { ここで }
$$

CLint $=\mathrm{V}_{\max } /(\mathrm{Km}+\mathrm{fb} \cdot \mathrm{Cliver} / \mathrm{Kp})$

$$
\mathrm{V}_{\max }=\mathrm{V}_{\max }(0) \cdot \text { Eact } / \mathrm{E}_{0}
$$

$\mathrm{Vpv} \cdot(\mathrm{dCpv} / \mathrm{dt})=\mathrm{Qh} \cdot \mathrm{Csys}-\mathrm{Qh} \cdot \mathrm{Cpv}$

Vsys $\cdot(\mathrm{dCsys} / \mathrm{dt})=\mathrm{Qh} \cdot$ Cliver $/ \mathrm{Kp}$

$$
-\mathrm{Qh} \cdot \mathrm{Csys}-\mathrm{CLr} \cdot \mathrm{Csys}
$$

BVUについて

Vliver $\cdot($ dIliver $/ \mathrm{dt})=\mathrm{Qh} \cdot \mathrm{Ipv}-\mathrm{Qh} \cdot$ Iliver $/ \mathrm{Kp}$ $-\mathrm{fb} \cdot \mathrm{CLint} \cdot$ Iliver/Kp (14)

$\mathrm{Vpv} \cdot(\mathrm{dIpv} / \mathrm{dt})=\mathrm{Qh} \cdot \mathrm{Isys}+\mathrm{Vabs}-\mathrm{Qh} \cdot \mathrm{Ipv}$ $\mathrm{Vabs}=\mathrm{ka} \cdot \mathrm{D} \cdot \mathrm{Fa} \cdot \mathrm{e}^{-\mathrm{ka} \cdot \mathrm{t}}$

Vsys $\cdot($ dIsys $/ \mathrm{dt})=\mathrm{Qh} \cdot$ Iliver $/ \mathrm{Kp}-\mathrm{Qh} \cdot$ Isys 
ここで Vliver, Vpvは肝蔵および門脈内容積, Vsys は 分布容積, Pliver, Cliver は肝臓中濃度, Ppv, Cpv, Ipv は門脈血中濃度, Psys, Csys, Isys は循環血中濃度, CLint は代謝固有クリアランス, CLint, 1 は 5-FU 生成 以外の CLint, CLint, 2 は 5-FU 生成の CLint, CLr は腎 クリアランス, Vabs は吸收速度をあらわす。

これらの式に文献情報より得た各薬物の体内動態パラ メータおよび in vitro 試験により得られた阻害パラメー タ ( $\mathrm{k}_{\text {inact }}$ と K'app) を代入し，数值的に解くことにより, tegafur $(2500 \mu \mathrm{mol}$, b.i.d $)$ を経口投与したときの sorivudine (50 mg, t.i.d)の併用効果についてシミュレーショ ンした. Fig. 5 に示すように, sorivudine の投与に伴 い肝蔵中活性型 DPD は急激に減少し, そのほとんどが 不活化されることが予測された. 5-FU の血中濃度は sorivudine 非投与時と比較して大きく上昇し，AUC 予 測上昇率は 5.3 倍 (ヒト肝サイトゾル), 5.4 倍 (rhDPD) となった。

同様の方法論にしたがって我々は, CYP3A4 代謝に おける triazolam/erythromycin の相互作用についても 定量的な予測に成功している7) . 相互作用に mechanism-based inhibition が関与する場合，阻害剤が血中， 組織中から消失した後でも阻害効果が残存し, 重篤な副 作用につながることが考えられる. 今後, 医薬品を開発 する段階でこういった in vitro 試験を実施し, in vivo の 相互作用を予測することを是非提唱したい。

\section{5. 薬物代謝阻害剂の肝臓への 能動輸送の評価}

これをで述べてきたように, in vivo での薬物間相互 作用を定量的に予測するためには，Iu の正確な值を評 価することが重要なポイントとなるが，これをヒトにお いて測定することは難しい。 そのため多くの場合, 阻害 剂は受動拡散によって肝細胞内へ移行し, 定常状態にお いて肝蔵中と肝毛細血管中の非結合型濃度は等しいとの
仮定のもとで解析が行われてきた．しかし，阻害剤が肝 蔵内に能動輸送により濃縮的に取り込まれる場合には上 記の仮定は成立せず，血中濃度を基準にして阻害の程度 を予測すると過小評価することになる可能性がある。そ こで，ラット遊離肝細胞を用いた in vitro 試験により阻 害剂の肝細胞内への能動輸送性を評価し, 肝細胞への濃 縮を考慮することにより予測性の改善を試みた ${ }^{8)}$.

種々のCYP isozyme に対して強い阻害活性を示す cimetidine, quinidine, sulfaphenazole, erythromycin, ketoconazole, omeprazole を被験物質とした.これらの 阻害剂を添加したラット遊離肝細胞縣濁液を経時的にサ ンプリングし，細胞中とメディウム中それぞれの薬物濃 度から取り込み速度を算出した。肝細胞への薬物の influx には能動輸送と受動拡散の両方が関与し, 肝細胞 からの efflux は受動拡散のみによって起きると仮定す ると，FCCP あるいは rotenone などの ATP 枯渴剤は 薬物の能動輸送を阻害することから, ATP 枯渴剤が存 在するときの取り込み初速度は受動拡散による取り込み を表わすと考えられる，そこで，ATP枯渴剤の存在下 と非存在下に打ける取り込久初速度の比加ら, 定常状態 に抢ける細胞中とメディウム中の非結合型薬物の濃度比 (C/M ratio) を求めた(式(18)).

$\mathrm{C} / \mathrm{M}$ ratio $=(\mathrm{PSactive}+\mathrm{PSpassive}) / \mathrm{PSpassive}$

$$
=\mathrm{Vo}_{\mathrm{o}} / \mathrm{Vpassive}
$$

ここで, PSactive と PSpassiveはをれぞれ能動輸送と 受動拡散による薬物の細胞膜透過クリアランス, Vo は 生理的条件下における取り込反初速度, Vpassive は受 動拡散による取り込久初速度を表わす。算出された C/ $\mathrm{M}$ ratio を上記の $\mathrm{I}_{\mathrm{in}, \mathrm{u}}$ にかけることにより肝蔵中非結合 型濃度を推定し，文献情報に基づく薬物間相互作用の予 測を再検討した。

Quinidine および erythromycin のラット遊離肝細胞 への取り込みの経時変化を Fig. 6 に示す. ATP 枯渴㓮 存在下では取り込反初速度の低下が認められ，肝細胞内
(A)

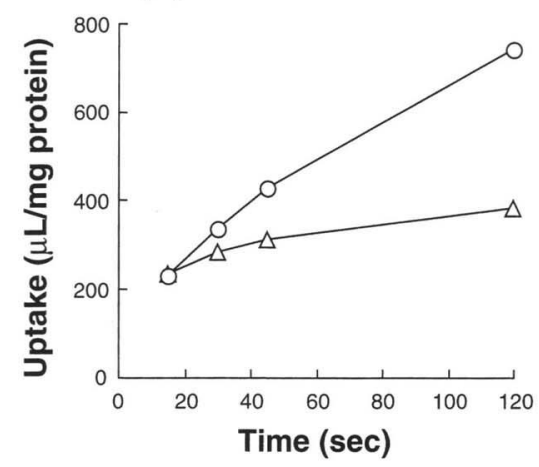

(B)

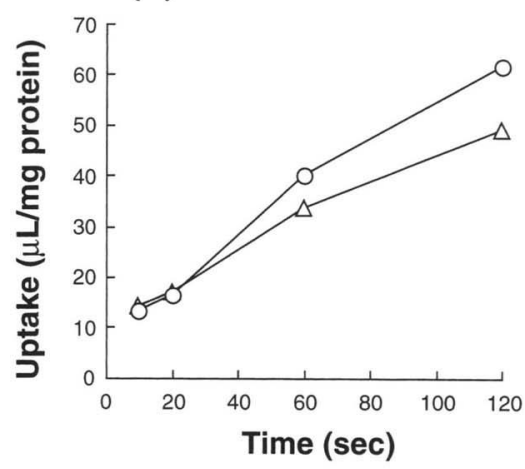

Fig. 6 Time courses of the uptake of $(\mathbf{A})\left[{ }^{3} \mathrm{H}\right]$ quinidine and $(\mathbf{B})\left[{ }^{14} \mathrm{C}\right]$ erythromycin into isolated rat hepatocytes. $\bigcirc$ : Control (in the absence of FCCP), $\triangle$ : in the presence of FCCP $(2 \mu \mathrm{M})$. 
Table III Prediction of in vivo drug-drug interactions

\begin{tabular}{|c|c|c|c|c|c|c|c|}
\hline \multirow{2}{*}{$\begin{array}{l}\text { Inhibitor } \\
\text { (Affected drug) }\end{array}$} & \multirow{2}{*}{$\mathrm{fh} \cdot \mathrm{fm}$} & \multirow{2}{*}{$\begin{array}{l}\mathrm{C} / \mathrm{M} \\
\text { ratio }\end{array}$} & \multicolumn{2}{|c|}{ - Active Transporta) } & \multicolumn{2}{|c|}{+ Active Transport ${ }^{\mathrm{b})}$} & \multirow{2}{*}{$\begin{array}{l}\text { Observed } \\
\text { AUC ratio }\end{array}$} \\
\hline & & & $\mathrm{Iu} / \mathrm{Ki}$ & $\begin{array}{l}\text { Predicted } \\
\text { AUC ratio }\end{array}$ & $\mathrm{Iu} / \mathrm{Ki}$ & $\begin{array}{l}\text { Predicted } \\
\text { AUC ratio }\end{array}$ & \\
\hline $\begin{array}{l}\text { Cimetidine } \\
\text { (Theophylline) }\end{array}$ & 0.52 & $\times 4.3$ & 0.05 & $\times 1.0$ & 0.2 & $\times 1.1$ & $\times 1.5$ \\
\hline $\begin{array}{l}\text { Quinidine } \\
\text { (Sparteine) }\end{array}$ & 0.25 & $\times 2.2$ & 60 & $\times 1.3$ & 132 & $\times 1.3$ & $\times 2.9$ \\
\hline $\begin{array}{l}\text { Erythromycin } \\
\text { (Cyclosporine) }\end{array}$ & 0.76 & $\times 1.4$ & 0.6 & $\times 1.3$ & 0.8 & $\times 1.5$ & $\times 1.6$ \\
\hline $\begin{array}{l}\text { Sulfaphenazole } \\
\text { (Tolbutamide) }\end{array}$ & 0.80 & $\times 1.2$ & 200 & $\times 5.0$ & 240 & $\times 5.0$ & $\times 5.3$ \\
\hline $\begin{array}{l}\text { Ketoconazole } \\
\text { (Terfenadine) }\end{array}$ & 0.58 & $\times 1.2$ & 4 & $\times 1.3$ & 5 & $\times 1.3$ & $>\times 5.0$ \\
\hline $\begin{array}{l}\text { Omeprazole } \\
\text { (Diazepam) }\end{array}$ & 0.99 & $\times 1.0$ & 0.03 & $\times 1.0$ & 0.03 & $\times 1.0$ & $\times 2.0$ \\
\hline
\end{tabular}

a) The $I_{\text {in, }}$ calculated based on the model in Fig. 1 was used as Iu.

b) The product of the $I_{\text {in,u }}$ and the $C / M$ ratio was used as Iu.

への濃縮率は, 式(18)からそれぞれ 2.2 倍および 1.4 倍 と計算された. 今回用いたいずれの薬物についても大き な能動輸送性 (ラット遊離肝細胞への濃縮率) は認められ ず，文献情報に基づくin vivo に抢ける $\mathrm{AUC}$ 上昇の推 定值に大きく影響を与えるほどではなかった(Table III). しかし，ラットとヒトの細胞で種差があることも 考えられるので, 今後, ヒト肝細胞あるいは肝スライス を用いて同様の検討をすることにより予測精度の向上が 可能となるであろう.

\section{6. · 新規薬物の代謝阻害の予測}

以上の検討結果をふをえて, 開発中の新規薬物の in vivo において併用されることの予想される他剤による代 謝阻害の可能性を予測する手順について propose する と, 以下のようになる.

1）In vitroに打いて, 目的とする新規薬物の代謝が P450によるものか否かを SKF-525A やCO による阻 害試験等により確認する.

2）目的化合物の代謝が P 450 によることが確認され たら, 各種ヒト P450 発現系ミクロソームを用いた代謝 試験や, 各種 P450 isozyme に対する抗体あるいは特異 的な阻害剂を用いた阻害試験等により, 関与する 4450 isozyme を同定する.

3）目的化合物の代謝に関与する P450 分子種を阻害 する可能性のある併用他剤のin vivo における体内動態 情報を調べ，最大血中非結合型濃度を算出する.

4）阻害剤の肝臓における能動的な取り込みをヒ卜肝 細胞あるいはそれが不可能であればラット遊離肝細胞を 用いて測定し, 肝臓への濃縮度を算出する. そのような 試験が無理な場合は, 約 $5 \sim 10$ 倍のマージンをとって Iu とする.

5）In vitro 代謝試験により目的化合物の代謝に対す
る阻害剤の Ki 值を求める。ここで, 阻害の程度が酵素 と阻害剤との preincubation 時間に依存する場合は mechanism-based inhibition の関与が考えられ，上記 4. の方法論を適用する必要がある.

6）4）で得られた $\mathrm{Iu}$ と 5) で求めた $\mathrm{Ki}$ を比較して, $\mathrm{Iu} / \mathrm{Ki}$ が $0.3 \sim 1$ を越える場合には, in vivoにおいて目 的化合物の代謝が阻害される危険性ありと判断する.

今後, 種々の情報を得ることによって, 本方法論をよ り予測性の良いものに改良していくことが必要であろ う.

\section{7. 胆汁排泄過程における相互作用の予測： Methotrexate (MTX) と Probenecid を例に}

近年, 肝臓や腎蔵において各種トランスポーターによ り取り込みや排泄を受ける薬物が数多く見いだされつつ ある. 取り込みや排泄過程における相互作用は, 臨床報 告例としては少ないものの今後無視できない状況となる であろう。したがって, 薬物代謝ばかりでなく排泄過程 における相互作用の受けやすさについても, in vitro 試 験からの定量的な評価が望屯れる。我々は排泄過程にお ける相互作用の例として, 抗癌剤 methotrexate (MTX)に対する probenecid (PBD)の相互作用 ${ }^{9)}$ を例に とり, in vivo で観察される胆汁排泄過程における薬物 間相互作用を in vitro 試験から定量的に予測する方法論 の確立を目的として, in vitro/in vivo の定量的比較が可 能なラットを用い検討を行った.

薬物の排泄に抢いては血管側膜, 管腔側膜の 2 つの 生体膜を透過する必要がある(Fig. 7)，したがって相互 作用もこれら 2 つを同時に考虑しなければならない。 肝臓においては血管側膜における取り込み(固有クリア 


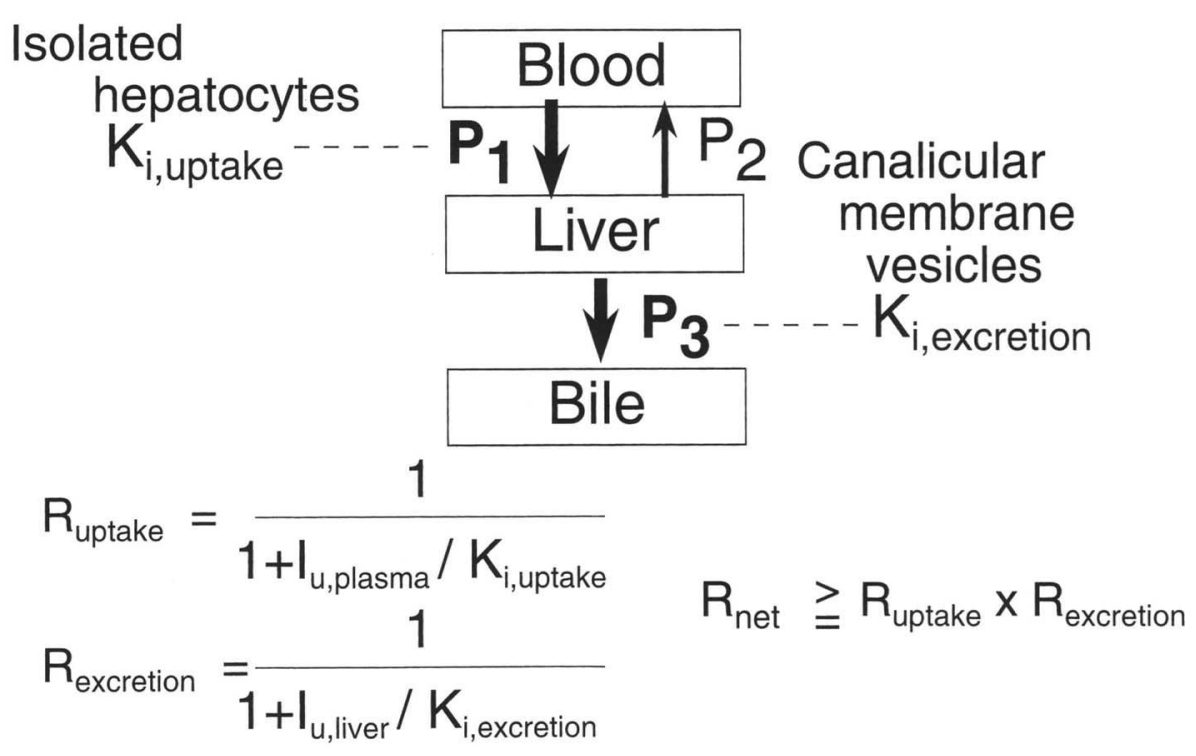

Fig. 7 Strategy for in vitro/in vivo extrapolation of drug interaction via hepatic transporters.

Table IV Prediction of drug interaction at hepatobiliary transport of MTX

\begin{tabular}{|c|c|c|c|c|c|c|c|c|}
\hline & \multicolumn{2}{|l|}{$\mathrm{P} 1$} & \multicolumn{2}{|c|}{ P3 } & \multicolumn{2}{|c|}{$\mathrm{CL}_{\text {bile, int }}$} & \multirow{2}{*}{$\begin{array}{c}\mathrm{I}_{\mathrm{u}, \text { plasma }}{ }^{\mathrm{a})} \\
\mu \mathrm{M}\end{array}$} & \multirow{2}{*}{$\begin{array}{c}\mathrm{I}_{\mathrm{u}, \text { liver }}{ }^{\mathrm{b})} \\
\mu \mathrm{M}\end{array}$} \\
\hline & $\begin{array}{c}\text { (observed) } \\
\mathrm{ml} / \mathrm{min} / \mathrm{kg}(\%)\end{array}$ & $\underset{\%}{\text { (predicted) }}$ & $\begin{array}{c}\text { (observed) } \\
\mathrm{m} l / \mathrm{min} / \mathrm{kg}(\%)\end{array}$ & $\underset{\%}{\text { (predicted) }}$ & $\begin{array}{c}\text { (observed) } \\
\%\end{array}$ & $\begin{array}{c}\text { (predicted) } \\
\%\end{array}$ & & \\
\hline Control & $24.3(100)$ & 100 & $20.0(100)$ & 100 & 100 & 100 & 0 & 0 \\
\hline $\begin{array}{l}\text { +Probenecid } \\
(2.2 \mu \mathrm{mol} / \mathrm{min} / \mathrm{kg})\end{array}$ & $16.4(67.6)$ & 55.4 & $12.2(61.0)$ & 45.0 & 51.5 & 24.9 & 145 & 63.2 \\
\hline $\begin{array}{l}+ \text { Probenecid } \\
(4.4 \mu \mathrm{mol} / \mathrm{min} / \mathrm{kg})\end{array}$ & $10.3(49.7)$ & 41.9 & $10.5(52.3)$ & 28.4 & 25.7 & 11.9 & 250 & 130 \\
\hline
\end{tabular}

a) Unbound probenecid concentration in the plasma.

b) Unbound probenecid concentration in the liver.

ランス $\mathrm{P}_{1}$ で定義), 細胞内から血液側への排出(固有ク リアランス $\mathrm{P}_{2}$ ), 細胞内から胆汁側への排泄 (固有クリ アランス $\mathrm{P}_{3}$ )の 3 つの素過程での相互作用が考えられ る.これら素過程を分離して評価し, 最終的に net の胆 汁排泄 (血液から胆汁をでの輸送, 固有クリアランス $\mathrm{CL}_{\text {int, bile }}$ で表す)の相互作用を予測する．このうち， $\mathrm{P}_{1}$ と $\mathrm{P}_{3}$ については遊離肝細胞ならびに胆管側膜ベシクル を用いた評価が可能である. 実際, MTX は両実験系で 能動輸送が証明されている10,11). ラットにおける解析か ら PBD はそれぞれの系におけるMTXの輸送に対して 濃度依存的な阻害を示し，Ki はそれぞれ約 $180 \mu \mathrm{M}$, 約 $50 \mu \mathrm{M}$ であった. したがって本質的な阻害効果は取 り込名側よりも排泄側のほうが強いことが示唆された。

次に相互作用の in vivo 実験系の確立を行った. PBD とMTX の同時定速静脈内投与によってMTXの血漿 中濃度は単独投与の際と比べて上昇し, 胆汁, 尿中排泄 はともに阻害された. 定常状態において肝蔵中非結合型 MTX 濃度の測定を行いMTXの $\mathrm{P}_{3}$ を実測したところ， PBD による低下が認められた(Table IV).ささらに定常
状態下 tracer $\left[{ }^{3} \mathrm{H}\right] \mathrm{MTX}$ を単回静注することにより積 分プロット解析から MTXの $\mathrm{P}_{1}$ を測定したところここ れもPBDによって低下していた(Table IV)。したがっ て PBD はin vivoに打いてもMTXの取り込み, 排泄 ともに阻害することが示された。

Fig. 7 に予測の基本ストラテジーを示した. 代謝の ケースと同様, 阻害剤(非結合型濃度 $\mathrm{Iu}$ ) 存在下に抢け る MTX の輸送クリアランス $\left(\mathrm{P}_{1}, \mathrm{P}_{2}, \mathrm{P}_{3}\right)$ はコントロー ルに対する比として,

$$
\mathrm{R}_{\text {uptake }} \text { or } \mathrm{R}_{\text {excretion }}=1 /(1+(\mathrm{Iu} / \mathrm{Ki}))
$$

で表される、ここで $\mathrm{R}_{\text {uptake }}, \mathrm{R}_{\text {excretion }}$ はそれぞれ $\mathrm{P}_{1}$ およ び $\mathrm{P}_{3}$ の阻害剤存在下の值を非存在下の值で除した值を 示す. $\mathrm{Ki}$ は遊離肝細胞 $(\mathrm{Ki}$, uptake), 胆管側膜ベシクル $(K i$, excretion $)$ から測定可能である.Iuは阻害剤である PBD の非結合型薬物濃度であり, 取り込久側では肝細 胞外液中, 排泄側では肝細胞内における濃度 $\left(\mathrm{I}_{\mathrm{u}}\right.$, liver $)$ を 意味する。肝細胞外液中の非結合型薬物濃度は, PBD のようなクリアランスの低い化合物を静注したケースで は血墏中のそれ $\left(\mathrm{I}_{\mathrm{u}, \text { plasma }}\right)$ で代用が可能である.クリア 
ランスの高い化合物や不明な化合物の場合でも, 肝細胞 外液中の非結合型薬物濃度は $\mathrm{I}_{\mathrm{u}, \text { plasma }}$ を越えることはな い.したがって false negative な予測を避けるという観

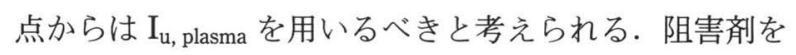
経口投与したケースでは, 上述の代謝の場合と同様, 肝 臟に流入する血液中の非結合型濃度を用いるべきであ る. 本試験はラットを用いているため $I_{u, \text { plasma }}, I_{u}$, liver と も実測している。ここで肝臓中非結合型分率は肝ホモジ ネートを用いた結合実験から求めた。式(19)により MTX の $\mathrm{P}_{1}$ ならびに $\mathrm{P}_{3}$ を予測したところ実測值と近い 值が得られ(Table IV), 血管側および胆管側の膜透過 過程を個々に予測する限りにおいては, in vitro 試験で 求めた Ki から相互作用の予測が可能であることが実証 された.

次に $\mathrm{CL}_{\text {int, bile }}$ の予測を考える. 現在のところ $\mathrm{P}_{2}$ の予 測に用いるべき有効な in vitro 試験系が存在しないこと から, false negative を避ける予測を考えた. すなわち, 最も阻害がかかるケースは阻害を受ける薬物が固有クリ アランス律速であり, かつ, $\mathrm{P}_{2} \gg \mathrm{P}_{3}$ のケースである. この場合, 取り込反側の $\mathrm{R}_{\text {uptake }}$ と排泄側の $\mathrm{R}_{\text {excretion }}$ の 積が $\mathrm{CL}_{\text {int, bile }}$ のコントロールに対する比 $\left(\mathrm{R}_{\mathrm{net}}\right)$ に相当す る、したがって $\mathrm{R}_{\text {net }}$ は $\mathrm{R}_{\text {uptake }}$ と $\mathrm{R}_{\text {excretion }}$ の積と等しい かまたはとれより大きくなる。

$$
\mathrm{R}_{\text {net }} \geqq \mathrm{R}_{\text {uptake }} \times \mathrm{R}_{\text {excretion }}
$$

式(20)に基づいた予測結果は相互作用をやや過大に評 価していたものの, 過小評価とはならなかった(Table IV). 過大評価の原因として MTX の胆汁排泄はコント ロール条件下では肝取り込み律速であるため, 排泄側の 阻害も考慮した式 $(20)$ が阻害の程度を過大に評価する 結果につながったためと考えられる. 但しここで $\mathrm{R}_{\text {excretion }}$ の予測には, 阻害剤の肝臓中非結合型濃度を用 いる必要がある.これはヒトでの測定がきわめて困難で あることから，上述の代謝過程に扔ける予測のケースと 同様, 能動輸送による濃縮率を考虑したうえ, 血漿中非 結合型濃度に適切な risk factor を掛けた值を用いるべ きと考えられる. また, 今回の解析では最も simpleな ケースとしてPBDの静注を行ったが，阻害剂を経口投 与するケースに扔いては, 式(1)に基づく阻害剤の門脈 中非結合型濃度を用いるべきと考える.これらについて も今後, 動物実験を行い, 予測の妥当性を検証する必要 がある.

\section{文献}

1) Ito K., Iwatsubo T., Kanamitsu, S., Nakajima Y., Sugiyama Y.: Quantitative prediction of in vivo drug clearance and drug interactions from in vitro data on metabolism together with binding and transport. Annu. Rev. Pharmacol. Toxicol. 38: 461-499 (1998).

2) Ito K., Iwatsubo T., Kanamitsu S., Ueda K., Suzuki H., Sugiyama Y.: Prediction of pharmacokinetic alterations caused by drug-drug interactions: Metabolic interaction in the liver. Pharmacol. Rev. 50: 387-411 (1998).

3) Veronese M. E., Miners J. O., Randles D., Gregov D., Birkett D. J.: Validation of the tolbutamide metabolic ratio for population screening with use of sulfaphenazole to produce model phenotypic poor metabolizers. Clin. Pharmacol. Ther. 47: 403-411 (1990).

4) Kanamitsu S., Ito K., Sugiyama Y.: Quantitative prediction of in vivo drug-drug interactions from in vitro data based on physiological pharmacokinetics: Use of maximum unbound concentration of inhibitor at the inlet to the liver. Pharm. Res., 17: 336-343 (2000).

5) Okuda H., Nishiyama T., Ogura K., Nagayama S., Ikeda K., Yamaguchi S., Nakamura Y., Kawaguchi Y., Watabe T.: Lethal drug interactions of sorivudine, a new antiviral drug, with oral 5-fluorouracil prodrugs. Drug Metab. Dispos. 25: 270-273 (1997).

6) Kanamitsu S., Ito K., Okuda H., Ogura K., Watabe T., Muro K., Sugiyama Y.: Prediction of in vivo drug-drug interaction based on mechanism-based inhibition from in vitro data: Inhibition of 5-fluorouracil metabolism by (E)5-(2-bromovinyl) uracil. Drug Metab. Dispos., 28: 467-474 (2000)

7) Kanamitsu S., Ito K., Green C. E., Tyson C. A., Shimada N., Sugiyama Y.: Prediction of in vivo interaction between triazolam and erythromycin based on in vitro studies using human liver microsomes and recombinant human CYP3A4. Pharm. Res., (in press).

8) Kanamitsu S., Shinozaki Y., Ito K., Iwatsubo T., Suzuki H., Sugiyama Y.: Quantitative prediction of in vivo drugdrug interactions from in vitro data: Effects of active transport of inhibitors into the liver. AATEX, (in press).

9) Aherne G. W., Piall E., Marks V., Mould G., White W. H.: Prolongation and enhancement of serum methotrexate concentrations by probenecid. Brit Med J 1: 1097-1099 (1978).

10) Gewirtz D., Randolph J. K., Goldman I. D.: Potent bile salt and organic anion inhibition of methotrexate uptake and accumulation in the freshly isolated rat hepatocyte. Cancer Res 40: 1852-1857 (1990).

11) Masuda M., I'izuka Y., Yamazaki M., Nishigaki R., Kato Y., Ni'inuma K., Suzuki H., Sugiyama Y.: Methotrexate is excreted into the bile by canalicular multispecific organic anion transporter in rats. Cancer Res. 57: $3506-3510$ (1997). 